\title{
PERANAN CUSTOMER SERVICE DALAM MENINGKATKAN PELAYANAN TERHADAP NASABAH PADA PT. BANK PERKREDITAN RAKYAT JORONG KAMPUNG TANGAH PARIAMAN CABANG PADANG
}

\author{
Nofriani Putri, Mariani St.B Tanjung \\ Akademi Keuangan dan Perbankan Padang \\ mstbtanjung@gmail.com
}

\begin{abstract}
ABSTRAK
Perkembangan dunia usaha saat ini termasuk sektor perbankan di kota Padang beberapa tahun belakangan ini mengalami kemajuan yang sangat pesat, perkembangan ini berkait dengan adanya sektor ekonomi nasional, adanya berbagai kemudahan yang diberikan oleh pemerintah dengan menciptakan cara atau suasana yang baik bagi perkembangan usaha di bidang perbankan di Indonesia. Hal ini di buktikan dengan banyaknya bank baru yang membuka kantor cabang di Sumatera Barat terutama di Kota Padang. Perbankan merupakan segala sesuatu yang menyangkut tentang bank, kelembagaan, kegiatan usaha, serta cara dan proses dalam melaksanakan kegiatan usahanya,dimana fungsi utamanya adalah sebagai penghimpun dana dari masyarakat dan menyalurkan kembali kepada masyarakat melalui kredit, yang bertujuan untuk menunjang pelaksanaan pembangunan dan hasil-hasilnya, serta pertumbuhan ekonomi bagi kehidupan rakyat banyak. Banyaknya bank yang ada di Indonesia saat ini, membuat persaingan semakin ketat dan berlomba untuk memperoleh peringkat paling baik dimata masyarakat, khususnya di Kota Padang. Oleh sebab itu, diperlukan strategi yang baik oleh masing-masing bank guna meningkatkan laba dan memiliki kualitas yang baik. Salah satu cara bank yang tepat adalah adanya Peranan Customer Service (CS) dalam meningkatkan pelayanan pelanggan terhadap nasabah di bank atau instansi lain , karena pelayanan pelanggan yang bermutu merupakan kunci sukses dan dasar untuk membangun keberhasilan di suatu perusahaan.
\end{abstract}

Kata Kunci : Customer Service, Nasabah 


\section{LATARBELAKANG}

Perkembangan dunia usaha saat ini termasuk sektor perbankan di kota Padang beberapa tahun belakangan ini mengalami kemajuan yang sangat pesat, perkembangan ini berkait dengan adanya sektor ekonomi nasional, adanya berbagai kemudahan yang diberikan oleh pemerintah dengan menciptakan cara atau suasana yang baik bagi perkembangan usaha di bidang perbankan di Indonesia. Hal ini di buktikan dengan banyaknya bank baru yang membuka kantor cabang di Sumatera Barat terutama di Kota Padang.

Perbankan merupakan segala sesuatu yang menyangkut tentang bank, kelembagaan, kegiatan usaha, serta cara dan proses dalam melaksanakan kegiatan usahanya,dimana fungsi utamanya adalah sebagai penghimpun dana dari masyarakat dan menyalurkan kembali kepada masyarakat melalui kredit, yang bertujuan untuk menunjang pelaksanaan pembangunan dan hasil-hasilnya, serta pertumbuhan ekonomi bagi kehidupan rakyat banyak.

Banyaknya bank yang ada di Indonesia saat ini, membuat persaingan semakin ketat dan berlomba untuk memperoleh peringkat paling baik dimata masyarakat, khususnya di Kota Padang. Oleh sebab itu, diperlukan strategi yang baik oleh masing-masing bank guna meningkatkan laba dan memiliki kualitas yang baik. Salah satu cara bank yang tepat adalah adanya Peranan Customer Service (CS) dalam meningkatkan pelayanan pelanggan terhadap nasabah di bank atau instansi lain, karena pelayanan pelanggan yang bermutu merupakan kunci sukses dan dasar untuk membangun keberhasilan di suatu perusahaan.

Adapun yang menjadi permasalahan yang akan penulis bahas dalam penelitian ini yaitu: "Bagaimana Peranan Customer Service dalam memberikan pelayanan terhadap nasabah di Bank Perkreditan Rakyat (JKT) Pariaman Cabang Padang"?

\section{LANDASANTEORI}

\section{Pengertian Bank}

Menurut Undang-UndangPasal 1 ayat 2Undang-UndangNo. 10 Tahun 1998 tentang perubahanUndang-UndangRepublikIndonesi No. 7 tahun 1992 tentangperbankan:"Bank adalah badan usaha yang menghimpun dana dari masyarakat dalam bentuk simpanan dan menyalurkannya kembali kepada masyarakat dalam bentuk kredit dan atau bentuk-bentuk lainnya dalam rangka meningkatkan taraf hidup rakyat banyak."

MenurutPasal 5 ayat 1 Undang-Undang No. 10 tahun 1998 yang $\begin{array}{lllll}\text { merupakanperubahanUndang-Undang } & \text { No. } & 7 & \text { tahun } & 1992\end{array}$ tentangPerbankan,membagi bank dalam 2 jenisyaitu : 
1. Bank Umum

Bank yang melaksanakan kegiatan usaha secara konvensional dan atau berdasarkan prinsip syariah yang dalam kegiatannya memberikan jasa dalam lalu lintas pembayaran.

2. Bank Perkreditan Rakyat

Bank yang melaksanakan kegiatan usahanya secara konvensional atau berdasarkan prinsip syariah yang dalam kegiatannya tidak memberikan jasa dalam lalu lintas pembayaran.

Berdasarkan pendapat diatas, maka dapat ditarik kesimpulan, Bank adalah lembaga keuangan yang usaha pokoknya memberikan kredit dan jasa-jasa dalam lalu lintas pembayaran dan peredaran uang.

\section{Tujuan Bank}

Berdasarkan Undang-Undang No. 10 tahun 1998 tentang perubahan Undang-Undang Republik Indonesia No. 7 tahun 1992 tentang perbankan, Perbankan Indonesia dalam melakukan usahanya berasaskan demokrasi ekonomi dengan prinsip kehati-hatian.Demokrasi ekonomi itu sendiri dilaksanakan berdasarkan Pancasila dan Undang-Undang1945.

Berdasarkan asas yang diatas, maka tujuan perbankan Indonesia adalah menunjang pelaksanaan pembangunan nasional dalam rangka meningkatkan pemerataan pembangunan dan hasil-hasilnya, pertumbuhan ekonomi, dan stabilitas nasional ke arah peningkatan kesejahteraan rakyat banyak.

\section{Fungsi Bank}

Fungsiutama bank adalah menghimpun dana dari masyarakat dan menyalurkannya kembali kepada masyarakat untuk berbagai tujuan atau sebagai financial intermediary.

\section{Jenis Bank}

\section{a. Bank Umum}

Bank umum adalah bank yang melaksanakan kegiatan usaha secara konvensional dan atau berdasarkan prinsip syariah yang dalam kegiatannya memberikan jasa lalu lintar pembayaran. Sifat jasa yang diberikan adalah umum, dalam arti dapata memberikan seluruh jasa perbankan yang ada. Begitu juga dengan wilayah operasinya dapat dilakukan diseluruh wilayah. Bank umum disebut jugabank komersil (commercial bank).

b. Bank Perkreditan Rakyat ( BPR )

Bank perkreditan Rakyat ( BPR ) adalah bank yang melaksakan kegiatan usaha secara konvensional atau berdasarkan prinsip syariah yang dalam kegiatannya tidak memberikan jasa dalam lalu lintas pembayaran. Artinya disini kegiatan BPR jauh lebih sempit jika dibandingkan dengan kegiatan bank umum.

\section{Pengertian Customer Service}

Pengertian Customer Service secara umum adalah setiap kegiatan yang diperuntukan atau ditujukan untuk memberikan kepuasan kepada 
nasabah melalui pelayanan yang dapat memenuhi keinginan dan kebutuhan nasabah.

\section{Tugas seorang Customer Service}

Dalam praktiknya fungsi Customer Service adalah sebagai resepsionis, sebagai deskman, sebagai salesman, sebagai Customer Relation Officer, sebagai Komunikator.

\section{Sikap dan Perilaku Seorang Customer Service}

Sikap dan perilaku merupakan bagian terpenting dalam perbankan. Adanya sikap dan perilaku yang harus di jalankan oleh setiap pegawai bank adalah jujur dalam bertindak dan bersikap, rajin, tepat waktu ,dan tidak pemalas, selalu murah senyum, lemah lembut dan ramah tamah, sopan santun tutur sapa dan hormat, bertanggung jawab dan suka menolong nasabah.

\section{METODEPENELITIAN}

Jenispenelitian yang digunakan peneliti dalam penelitian ini yaitu deskriptif kuantitatif, penelitian ini dilakukan di PT. BankPerkreditanRakyat( JKT ) PariamanCabang Padang, yang beralamat Jl. Adinegoro Km 15 Lubuk Buaya Padang. Data yang digunakan adalah data sekunder.

Dalam pengumpulan data dan bahan untuk melakukan penelitian ini, digunakan metode-metode pengumpulan data

a. Studi lapangan

Pada penelitian ini dilakukan dengan cara melakukan pengamatan langsung dan melakukan wawancara dengan pihak-pihak yang terkait.

b. Studi Kepustakaan

Penelitian ini dilakukan dengan mengumpulkan data dan menggunakan teori-teori yang berkaitan dengan masalahmasalah yang akan di bahas, yang di peroleh dari literature yang ada berupa buku-buku yang berkaitan dengan masalah.

\section{HASIL DAN PEMBAHASAN}

1. Peranan Customer Service dalam Meningkatkan Pelayanan Terhadap Nasabah

Peranan seorang Customer Service dalam meningkatkan pelayanan terhadap nasabah pada PT. Bank Perkreditan Rakyat Jorong Kampung Tangah (JKT) Pariaman Cabang Padang merupakan kunci sukses dan dasar untuk membangun keberhasilan bank tersebut. Oleh karena itu, segala kegiatan harus berjalan dengan baik dan bermutu demi terciptanya kepuasan nasabah. Karena nasabah yang merasa mendapatkan kepuasan akan kembali lagi mendatangi bank tersebut dan membeli produk lain yangditawarkan oleh bank serta akan berbagi cerita dengan rekan yang lainnya. 
2. Fungsi Customer Service Pada Bank Perkreditan Rakyat Jorong Kampung Tangah Pariaman

Dalam praktiknya fungsi Customer Service adalah sebagai resepsionis, sebagai deskman, sebagai salesman, sebagai customer relation officer, sebagaikomunikator.

3. AktivitasPembukaanRekeningOleh Customer Service

Adapun aktivitas yang dilakukan oleh Customer service di Bank Bank Perkreditan Rakyat Jorong Kampung Tangah (JKT) Pariaman Cabang Padang adalah sebagai berikut :

1. Pembukuan rekening dan penutupan rekening.

a. Rekening Giro.

b. Rekening Tabungan.

c. DepositoBerjangka.

2. Informasi saldo rekening giro dan tabungan.

3. Pemesanan dan mencetak buku cek atau bilyet giro dan tabungan.

4. Penyerahaan atau pengiriman buku cek atau bilyet giro.

5. Aktivitaslainnya non-tunai.

a. Memeliharadokumen.

b. Melakukan reminder.

c. Pemeliharaan data nasabah.

\section{KESIMPULANDAN SARAN}

1. Kesimpulan

Berdasarkan uraian dan pembahasan yang telah dikemukakan dalam bab sebelumnya, maka dapat diambil kesimpulan sebagai berikut :

1) Customer Service adalah seorang komunikator dengan cara memberikan segala informasi dan kemudahan-kemudahan kepada nasabah dan juga sebagai tempat menampung keluhan, keberatan, atau konsultasi antara kepentingan bank dengan kepentingan nasabah.

2) Customer Service memegang peranan sangat penting dalam memberikan pelayanan dan dituntut untuk selalu berhubungan dengan nasabah dan menjaga hubungan itu tetap baik. Hal ini tentu saja harus dilakukan karena menjaga hubungan yang baik dengan nasabah juga berarti menjaga image bank agar citra bank dapat terus meningkat di mata nasabah.

3) Bahwasanya peran Customer Service dalam meningkatkan loyalitas nasabah sangatlah penting melalui pelayanan yang diberikan oleh bagian Customer Service. Pelayanan Customer Service berupa memberikan kemudahan kepada para nasabah. 
2. Saran

Saran yang dapat diberikan penulis sehubungan dengan uraian-uraian sebelumnya adalah sebagai berikut :

1) Dalam memberikan pelayanan, Customer Service harus ramah dan selalu dituntut agar dapat memuaskan nasabah tanpa melanggar harga diri atau etika.

2) Apabila ada masalah atau pengaduan dari nasabah tentang produk dan jasa yang ditawarkan, agar Customer Service dengan sabar mendengarkan segala keluhan yang dihadapi nasabah.

3) Kinerja Customer Service terus ditingkatkan, karena peranan Customer Service sangat penting dan merupakan tulang punggung kegiatan operasional. Dalam dunia Perbankan sebaiknya pihak bank perlu memberikan ketrampilan yang lebih bagi Customer Service. Dalam hal ini berupa training tambahan dengan dukungan sarana dan prasarana yang memadai. Dengan training tersebut diharapkan bias memberikan kepuasan pada nasabah dengan memberikan pelayanan yang terbaik.

\section{DAFTARPUSTAKA}

Budisantoso, Totok dan Sigit Triandaru. 2000. Bank dan Lembaga Keuangan Lainnya, Jakarta.

Marlius, D. (2018). Loyalitas Nasabah Bank Nagari Syariah Cabang Bukittinggi Dilihat Dari Kualitas Pelayanan. Jurnal Pundi. Volume 1. No. 3. Hal.12-22. https://doi.org/10.31575/jp.v1i3.60

Fernandes, Y. D., \& Marlius, D. (2018). Peranan Customer Service Dalam Meningkatkan Pelayanan Kepada Nasabah Pada PT. Bank Pembangunan Daerah Sumatera Barat Cabang Utama Padang. https://doi.org/10.31227/osf.io/wrh3p

Kasmir, SE.,MM, 2007 Dasar-dasar Perbankan, PT. Raja Grafindo Persada,

Martini, William B, 2004, Quality Customer Service, Penerbit PPM, Jakarta.

Mirawati \& Fernos, J. (2019). Peranan Customer Service Dalam Meningkatkan Pelayanan Terhadap Nasabah Pada Bank Nagari Cabang Siteba Padang. https://doi.org/10.31227/osf.io/cq458

Putra, A. M., \& Fernos, J. (2019). Pelaksanaan Pelayanan Prima Terhadap Kepercayaan Nasabah Di PT. Bank Perkreditan Rakyat Jorong Kampung Tangah Pariaman. https://doi.org/10.31227/osf.io/c3fy4 
Sunarto, 2006, Customer Service, Penerbit Amus, Yogyakarta.

Situmorong, Syafrizal Helmi, 2008, Perencanaan dan Pengembangan Bisnis Penerbit USU Press, Medan.

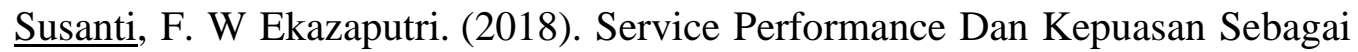
Moderating Variabel Terhadap Loyalitas Nasabah Pada PT BPR Labuh Gunung Payakumbuh Jurnal Benefita: Ekonomi Pembangunan Manajemen Bisnis Dan Akuntansi. Volume 3. No. 3. Hal. 433444.http://doi.org/10.22216/jbe.v3i3.3472

Tiza, M. F., \& Susanti, F. (2019). Pengaruh Kualitas Pelayanan Terhadap Kepuasan Pelanggan, Studi kasus pada perusahaan JNE Cabang Padang. https://doi.org/10.31227/osf.io/hx87m

Undang-undang Perbankan Nomor 10 Tahun 1998 Tentang Perubahan Undang-

Undang Nomor 7 Tahun 1992 Tentang Perbankan. Jakarta: Sinar Grafika.

Widayati, R. (2019). Upaya Meningkatkan Minat Untuk Menabung Pada PT. BPR Batang Kapas. https://doi.org/10.17605/OSF.IO/AEVW7

Widayati, R. (2019). Upaya Meningkatkan Nasabah Tabungan Melalui Tabungan Bajapuik Pada PT. Bank Perkreditan RakyaT (BPR) Jorong Kampuang Tangah (JKT) Pariaman. https://doi.org/10.17605/OSF.IO/36M48

Yuvendri, R., \& Susanto, R. (2019). Meningkatkan Mutu Pelayanan Dalam Usaha Menghimpun Dana Masyarakat (Tabungan) Pada PT. Bank Perkreditan Rakyat Prima Mulia Anugrah Cabang Padang. https://doi.org/10.31219/osf.io/6prcd 